\title{
KINETIC DEGRADATION OF TOTAL PHENOLIC CONTENT, DPPH RADICAL SCAVENGING AND XANTHINE OXIDASE INHIBITORY ACTIVITIES IN YANANG (Tiliacora triandra) LEAF EXTRACT DURING PREPARATION PROCESS
}

\section{(Degradasi Kinetik Kandungan Jumlah Fenolik, Aktiviti Pemerangkapan Radikal DPPH dan Xantin Oksidase dalam Ekstrak Daun Yanang (Tiliacora triandra) Semasa Proses Penyediaan)}

\author{
Sunee Eadmusik ${ }^{1}$, Chanthima Phungamngoen ${ }^{1}$, Natthaya Choosuk ${ }^{2}$ \\ ${ }^{1}$ Department of Agro-industry Technology and Management, Faculty of Agro-industry \\ ${ }^{2}$ Department of Innovation and Product Development Technology, Faculty of Agro-industry \\ King Mongkut's University of Technology North Bangkok, 25230 Prachinburi, Thailand
}

*Corresponding author: sunee.e@agro.kmutnb.ac.th

Received: 25 October 2017; Accepted: 22 January 2019

\begin{abstract}
Presently, canned bamboo shoots in Yanang (Tiliacora triandra (Colebr.) Diels) leaf extract is produced in order to expand shelf-life and ease to prepare food. The objectives of this research were to investigate the effect of different thermal processing during Yanang leaf extract preparation on total phenolic content, DPPH radical scavenging and xanthine oxidase inhibitory activities and to determine kinetics of the extract's quality alterations. The preparation included 1:12 (w/v) leaves to water ratio, $32,000 \mathrm{rpm}$ blending speed and different heating temperature at 60,70 or $80{ }^{\circ} \mathrm{C}$ for 15 minutes. Data were collected at $0,1,3,6$, 9, 12 and 15 minutes of heating time. The results showed that fresh Yanang leaf extract had total phenolic content of $680.16 \pm$ $19.57 \mathrm{mg} \mathrm{GAE} / 100 \mathrm{mg} \mathrm{db}$. and it possessed DPPH radical scavenging and xanthine oxidase inhibitory activities at $163.53 \pm 0.87$ $\mu \mathrm{g} \mathrm{BHT} / \mathrm{mL}$ and $78.58 \pm 0.17 \%$, respectively. The results revealed that an increase in heating temperature and time decreased total phenolic content and the DPPH radical scavenging and xanthine oxidase inhibitory activities of Yanang leaf extract. During 15 minutes heating, the total phenolic content of Yanang leaf extract ranged from $526.33 \pm 28.79$ to $638.93 \pm 29.69 \mathrm{mg}$ GAE/100 $\mathrm{mg} \mathrm{db}$., DPPH radical scavenging activity ranged from $92.86 \pm 1.66$ to $136.41 \pm 5.70 \mu \mathrm{g} \mathrm{BHT} / \mathrm{mL}$ and xanthine oxidase inhibitory activity ranged from $72.64 \pm 0.34$ to $76.65 \pm 0.50 \%$. The change of total phenolic content $\left(\mathrm{R}^{2}=0.809-0.959\right)$ followed zero-order kinetic model and that of DPPH radical scavenging activity $\left(\mathrm{R}^{2}=0.783-0.920\right)$ while xanthine oxidase inhibitory activity $\left(\mathrm{R}^{2}=0.864-0.922\right)$ followed second-order kinetic model.
\end{abstract}

Keywords: Yanang, Tiliacora triandra, total phenolic content, xanthine oxidase, kinetic model

\begin{abstract}
Abstrak
Pada masa ini, pucuk buluh dalam ekstrak daun Yanang (Tiliacora triandra (Colebr.) Diels) yang ditinkan dihasilkan untuk meningkatkan hayat simpanan dan kemudahan untuk menyediakan makanan. Objektif penyelidikan ini adalah untuk mengkaji kesan pemprosesan terma yang berbeza semasa penyediaan ekstrak daun Yanang terhadap kandungan jumlah fenolik, aktiviti pemerangkapan radikal DPPH dan xantin oksidase dan untuk menentukan kinetik perubahan kualiti ekstrak. Penyediaan melibatkan nisbah daun kepada air, 1:12 (w/v) 32,000 rpm halaju adunan dan suhu pemanasan yang berbeza pada 60, 70 atau 80 ${ }^{\circ} \mathrm{C}$ selama 15 minit. Data dikumpulkan pada masa pemanasan 0, 1, 3, 6, 9, 12 dan 15 minit. Keputusan menunjukkan bahawa ekstrak daun Yanang segar mempunyai kandungan jumlah fenolik sebanyak 680.16 $\pm 19.57 \mathrm{mg}$ GAE/100 mg berat kering dan aktiviti pemerangkapan radikal DPPH dan xantin oksidase ialah $163.53 \pm 0.87 \mu \mathrm{g}$ BHT/mL dan $78.58 \pm 0.17 \%$. Keputusan menunjukkan bahawa peningkatan suhu pemanasan dan masa menurunkan kandungan jumlah fenolik dan aktiviti ekstrak daun
\end{abstract}




\section{Eadmusik et al: KINETIC DEGRADATION OF TOTAL PHENOLIC CONTENT, DPPH RADICAL SCAVENGING AND XANTHINE OXIDASE INHIBITORY ACTIVITIES IN YANANG (Tiliacora triandra) LEAF EXTRACT DURING PREPARATION PROCESS}

Yanang. Selepas 15 minit pemanasan, kandungan fenolik jumlah ekstrak daun Yanang ialah dari $526.33 \pm 28.79$ hingga $638.93 \pm$ $29.69 \mathrm{mg}$ GAE$/ 100 \mathrm{mg}$ berat kering, aktiviti perencatan radikal DPPH adalah daripada $92.86 \pm 1.66 \mathrm{hingga} 136.41 \pm 5.70 \mu \mathrm{g}$ $\mathrm{BHT} / \mathrm{mL}$ dan aktiviti perencatan xantin oksidase dalam julat $72.64 \pm 0.34$ hingga $76.65 \pm 0.50 \%$. Perubahan kandungan fenolik jumlah $\left(\mathrm{R}^{2}=0.809-0.959\right)$ adalah mengikut model kinetik tertib sifar dan aktiviti pemerangkapan radikal DPPH $\left(\mathrm{R}^{2}=0.783\right.$ $0.920)$ sementara aktiviti penghambatan xantin oksidase $\left(\mathrm{R}^{2}=0.864-0.922\right)$ adalah mengikut modeltertib kedua.

Kata kunci: Yanang, Tiliacora triandra, kandungan jumlah fenolik, xantin oksidase, model kinetik

\section{Introduction}

Tiliacora triandra (Colebr.) Diels belongs to the family of Menispermaceae. It is known in Thai as Yanang. Its leaf and root are widely used in the Southeast Asia countries due to its health benefits [1]. Traditionally, Yanang root has been used as antipyretic and antimalarial agents [2] while Yanang leaf has been used for anticancer and immune modulator [3]. Previous studies reveal that tiliacorinine, tiliacorine and nor-tiliacorinine are bisbenzylisoquinoline alkaloids found in Yanang [4, 5] and gum from Yanang has a similar structure to xylan according to their FTIR spectra [2]. Several studies also show that Yanang contains bioactive compounds, such as phenolic compounds, which possess significant antioxidant properties [6]. Ferulic acid, $p$-coumaric acid, sinapic acid and syringic acid are specific phenolic compounds presented in Yanang leaf extract. The ability to stabilize free radicals and break the oxidation chain of these phenolic compounds has been reported [7]. Yanang leaves are usually extracted with water to be cooked especially with bamboo shoots because of its remedy for gout (gouty arthritis). The treatment for gout involves the use of therapeutic agent such as xanthine oxidase inhibitors [8]. The enzyme, xanthine oxidase, converts hypoxanthine into xanthine and sequent into uric acid which can accumulate in human body and cause gout. However, the stability of bioactive compounds is unstable depending on the $\mathrm{pH}$, light, oxygen, temperature and enzymatic activities [9].

Several studies reported the degradation of phenolic compounds and antioxidant activity in fruits and vegetables during thermal processing $[10,11,12]$. Tian et al. [10] revealed that up to $72 \%$ of total phenolic content and $61 \%$ of 2,2-diphyneyl-2-picryl-hydrazyl (DPPH) radical scavenging activity in purple-fleshed potatoes decreased during cooking. Recently, Méndez Lagunas et al. [12] reported losses of 78\% total phenolic content and 74\% DPPH radical scavenging in strawberry during convective drying. Nevertheless, no information related with alteration of xanthine oxidase during thermal processing.

Presently, canned bamboo shoots in Yanang leaf extract is produced in order to expand shelf-life and ease to prepare food. The preparation process of Yanang leaf extract could impair the stabilities of bioactive compounds and properties. Therefore, the aims of this study were to investigate the effect of different thermal processing during Yanang leaf extract preparation on total phenolic content, DPPH radical scavenging and xanthine oxidase inhibitory (XOI) activities and to determine kinetics of the extract's property degradations.

\section{Chemicals and reagents}

\section{Materials and Methods}

All chemicals and reagent were analytical grade. Folin-Ciocalteu reagent was purchased from Loba Chemie Pvt Ltd. (Mumbai, India) while $\mathrm{Na}_{2} \mathrm{CO}_{3}$ was purchased from Ajax Finechem Pty Ltd. (Auckland, New Zealand). Tablets of sodium phosphate buffer were obtained from Amresco LLC (Ohio, USA). Xanthine and xanthine oxidase were obtained from Himedia Laboratories Pvt. Ltd. (Mumbai, India). Dimethyl sulfoxide (DMSO) was obtained from Sigma-Aldrich (Missouri, USA).

\section{Plant material and extraction}

Yanang (Tiliacora triandra) leaves, obtained from the local market in Prachinburi province of Thailand, were washed with excess water to remove dust and the infected leaves were discarded. Only consistent green-colored leaves with more than $3 \mathrm{~cm}$ width $x 5 \mathrm{~cm}$ length were collected. The collected leaves were then naturally dried and kept at $6{ }^{\circ} \mathrm{C}$ until used within 7 days. Fifty grams of Yanang leaves were mixed with $600 \mathrm{~mL}$ water (leaves to water ratio is 1:12) and blended using a Buono-17778P blender (Taiwan, ROC) at 32,000 rpm for 1 minute. The Yanang leaf extract was obtained by filtering through 2 layer-muslin cloth and adjusted to $600 \mathrm{~mL}$ with water. The Yanang leaf extract was freshly prepared before each experiment. 
In order to determine the kinetic degradation of chemical properties of Yanang leaf extract, the extract was heated at 60,70 and $80{ }^{\circ} \mathrm{C}$. The samples were collected at $0,1,3,6,9,12$ and 15 minutes after heating and total phenolic content, DPPH radical scavenging activity and XOI activity were determined.

\section{Determination of total phenolic content}

Total phenolic content determination was performed following the method described by Singthong et al. [6]. Briefly, $20 \mu \mathrm{L}$ of Yanang leaf extract were mixed with $1.58 \mathrm{~mL}$ of water and $100 \mu \mathrm{L}$ of Folin-Ciocalteu reagent. After 5 minutes incubation at room temperature, the mixture was added with $300 \mu \mathrm{L}$ of $2 \%$ (w/v) $\mathrm{Na}_{2} \mathrm{CO}_{3}$ and then placed in the dark at room temperature for 2 hours. Absorbance of the mixture was measured at $765 \mathrm{~nm}$ using an Optima SP-300 spectrophotometer from Optima Inc. (Tokyo, Japan). Gallic acid (0-200 mg/L) was used as a standard for the calibration curve. Total phenolic content of Yanang leaf extract was expressed as mg Gallic acid equivalent/100 mg dry basis (mg GAE/ $100 \mathrm{mg} \mathrm{db}$.).

\section{Determination of DPPH radical scavenging activity}

DPPH radical scavenging activity was measured following the method described by De Ancos et al. [13]. Ten $\mu \mathrm{L}$ of Yanang leaf extract were diluted with $90 \mu \mathrm{L}$ of water, mixed with $3.9 \mathrm{~mL}$ of $25 \mathrm{mM} \mathrm{DPPH}$ and placed in the dark for 30 minutes. Absorbance of the mixture was measured at $515 \mathrm{~nm}$. Butylhydroxytoluene (BHT) was used as a standard. DPPH radical scavenging activity of Yanang leaf extract was expressed as $\mu \mathrm{g}$ BHT/mL.

\section{XOI activity assay}

XOI activity with xanthine as the substrate was measured with the method described by Azmi et al. [8]. The assay mixture consisted of $300 \mu \mathrm{L}$ of $50 \mathrm{mM}$ sodium phosphate buffer $\mathrm{pH} 7.5,100 \mu \mathrm{L}$ of Yanang leaf extract sample, 100 $\mu \mathrm{L}$ of $0.2 \mathrm{U} / \mathrm{mL}$ freshly prepared xanthine oxidase in phosphate buffer and $100 \mu \mathrm{L}$ of distilled water. After preincubation at $37^{\circ} \mathrm{C}$ for 15 minutes, $200 \mu \mathrm{L}$ of $0.15 \mathrm{mM}$ xanthine was added into the mixture. The mixture was then incubated at $37{ }^{\circ} \mathrm{C}$ for 30 minutes. The reaction was stopped with the addition of $200 \mu \mathrm{L}$ of $0.5 \mathrm{M} \mathrm{HCl}$. The absorbance was measured spectrophotometrically at $295 \mathrm{~nm}$ against a blank which was prepared in the same way but the enzyme solution was replaced with phosphate buffer. An assay of control sample prepared by using $100 \mu \mathrm{L}$ DMSO instead of Yanang leaf extract sample was also performed in order to have a maximum uric acid formation. Allopurinol, a well-known xanthine oxidase inhibitor, was used as a positive control at a concentration of 100 $\mu \mathrm{g} / \mathrm{mL}$. Percentage of XOI activity was calculated as following (equation 1):

$$
\% \mathrm{XOI}=\left(\frac{A b s_{\text {control }}-A b s_{\text {extract sample }}}{A b s_{\text {control }}}\right) \times 100
$$

where $A b s_{\text {control }}$ is absorbance of control sample when DMSO was used. $A b s_{\text {sample }}$ is absorbance of Yanang leaf extract sample.

\section{Statistical analysis and development of kinetic model}

Experiments were carried out in triplicate. The data were expressed as mean \pm standard deviation. The means of all parameters were examined using analysis of variance (One-way ANOVA). Duncan's New Multiple Range Test (DMRT) was used to determine the multiple comparison of mean values at a level of $P<0.05$. Correlations were established by regression analysis. A SPSS statistical program version 16 was used to perform the calculation.

The data of degradation (quality-time curve) were fitted to three different kinetic models according to the following equations (2-4):

The zero order reaction; $\quad C=C_{0}-k t$

The first order reaction; $\quad \ln C=\ln C_{0}-k t$ 
The second order reaction; $\frac{1}{C}=\frac{1}{C_{0}}+k t$

where $C$ is quality (total phenolic content, DPPH radical scavenging activity or XOI activity) of Yanang leaf extract at time $t . C_{0}$ is initial quality (total phenolic content, DPPH radical scavenging activity or XOI activity) of Yanang leaf extract at time $0 . k$ is reaction rate constant and $t$ is time (minutes)

The effect of temperature on the degradation rate constant was assumed to follow the Arrhenius equation 5;

$$
k=k_{0} \exp \left[-E_{a} / \mathrm{RT}\right]
$$

where as $k$ is rate constant, $k_{0}$ is pre-exponential factor, $E_{a}$ is activation energy for the degradation $(\mathrm{J} / \mathrm{mol}), \mathrm{R}$ is gas constant $(8.314 \mathrm{~J} / \mathrm{mol} . \mathrm{K})$, and $\mathrm{T}$ is absolute temperature $(\mathrm{K})$.

\section{Total phenolic content}

\section{Results and Discussion}

The total phenolic content of Yanang leaf extract is shown in Figure 1(a). It varied from $526.33 \pm 28.79$ to $733.74 \pm$ $21.63 \mathrm{mg} \mathrm{GAE} / 100 \mathrm{mg} \mathrm{db}$. depending on the heating temperature and time. The preparation process at $80{ }^{\circ} \mathrm{C}$ for 15 minutes gave the least total phenolic content, $526.33 \pm 28.79 \mathrm{mg} \mathrm{GAE} / 100 \mathrm{mg} \mathrm{db}$. During 15 minutes heating at $60{ }^{\circ} \mathrm{C}$, the total phenolic content of Yanang leaf extract ranged from $594.85 \pm 28.32$ to $623.74 \pm 17.62 \mathrm{mg} \mathrm{GAE} / 100$ $\mathrm{mg} \mathrm{db}$. It ranged from $638.93 \pm 29.69$ to $680.78 \pm 43.54 \mathrm{mg} \mathrm{GAE} / 100 \mathrm{mg} \mathrm{db}$. and from $526.33 \pm 28.79$ to $733.74 \pm$ $21.63 \mathrm{mg} \mathrm{GAE} / 100 \mathrm{mg} \mathrm{db}$. for heating at $70{ }^{\circ} \mathrm{C}$ and $80{ }^{\circ} \mathrm{C}$, respectively. The results showed that an increase in heating temperature and time decreases the total phenolic content in Yanang leaf extract due to the fact that phenolic compounds are heat labile [14]. Compared with fresh Yanang leaf extract, a reduction of $2.03-22.62 \%$ in total phenolic content was observed in Yanang leaf extract after 15 minutes heating.

A previous study reported that the total phenolic content of 1:10 (w/v) ethanolic Yanang leaf extract incubated at 70 ${ }^{\circ} \mathrm{C}$ for 15 minutes was $8.60 \mathrm{mg} \mathrm{GAE} / \mathrm{g} \mathrm{db}$. [15]. Other study determined total phenolic content and antioxidant activities of $100 \mathrm{mg}$ Yanang leaf powder extracted separately with $12 \mathrm{~mL}$ water, ethanol or acetone in a shaking water bath at $25{ }^{\circ} \mathrm{C}$ for 15 minutes. It was found that, among the three solvents, the water extraction gave a great amount of phenolic compounds and high antioxidant activities [6]. The total phenolic content of the water extract was the highest (97.90 mg GAE/g) compared with the ethanol and acetone extracts which was 26.70 and $16.46 \mathrm{mg}$ $\mathrm{GAE} / \mathrm{g}$, respectively.

The difference in total phenolic content was a result of different extraction methods including sample preparation, type of solvent used, extraction temperature and extraction time. Based on the same solvent used and same basis (mg GAE/100 $\mathrm{mg} \mathrm{db}$.), the total phenolic content of Yanang leaf extract reported in the present study was much higher than that reported by Singthong et al. [6] (526.33-733.74 compared to $9.79 \mathrm{mg}$ GAE/100 $\mathrm{mg} \mathrm{db}$.). This finding might due to a different extraction method. According to Singthong et al. [6], Yanang leaves were dried at $60{ }^{\circ} \mathrm{C}$ for 3 hours and ground into powder before the extraction using a shaking water bath at $25{ }^{\circ} \mathrm{C}$ for 15 minutes whereas this present study extracted fresh Yanang leaves using a high speed blender at 32,000 rpm for 1 minute.

\section{DPPH radical scavenging activity}

The DPPH radical scavenging assay was performed to determine an antioxidant potential of Yanang leaf extract by donating a hydrogen atom to DPPH radical. The DPPH radical scavenging activity of Yanang leaf extract ranged from $92.86 \pm 1.66$ to $163.53 \pm 0.87 \mu \mathrm{g}$ BHT/mL as shown in Figure 1(b). The preparation process at $80{ }^{\circ} \mathrm{C}$ for 15 minutes gave the least DPPH radical scavenging activity, $92.86 \pm 1.66 \mu \mathrm{g}$ BHT/mL. During 15 minutes heating at $60{ }^{\circ} \mathrm{C}$, the DPPH radical scavenging activity of Yanang leaf extract ranged from $136.41 \pm 5.70$ to $160.49 \pm 2.60 \mu \mathrm{g}$ $\mathrm{BHT} / \mathrm{mL}$. The DPPH radical scavenging activity ranged from $109.54 \pm 1.41$ to $154.01 \pm 1.72 \mu \mathrm{g} \mathrm{BHT} / \mathrm{mL}$ and from $92.86 \pm 1.66$ to $121.99 \pm 3.07 \mu \mathrm{g} \mathrm{BHT} / \mathrm{mL}$ for heating at $70{ }^{\circ} \mathrm{C}$ and $80{ }^{\circ} \mathrm{C}$, respectively. Compared with fresh Yanang leaf extract, a reduction of $1.86-43.22 \%$ in DPPH radical scavenging activity was observed in Yanang leaf extract after 15 minutes heating. 
Considering the results, an increasing in heating temperature and time led to a decrease in the DPPH radical scavenging activity of Yanang leaf extract along with its total phenolic content (Figure 1a-b). This could be due to the fact that phenolic compounds possess an antioxidant activity. Thus, a reduction of total phenolic content subsequently resulted in a decrease in the DPPH radical scavenging activity. A rise in heating temperature and time not only diminished phenolic compounds but also accelerated a radical formation through the oxidation reaction [14].

Previous researches have studied on DPPH radical scavenging activity in Yanang leaf extract. Singthong et al. [6] investigated the DPPH radical scavenging activity of Yanang leaf powder extracted separately with water, ethanol or acetone and revealed that $\mathrm{IC}_{50}$ value of the extract was $0.197,0.333$ and $0.419 \mathrm{mg} / \mathrm{g}$, respectively. Other study reported the $\mathrm{IC}_{50}$ value of $16.19 \mathrm{ppm}$ in Yanang leaf extracted with water compared to that of $9.63 \mathrm{ppm}$ in Yanang leaf extracted with methanol [3]. However, Taejarerniriyakul et al. indicated that Yanang leaf extracted with methanol has an $\mathrm{IC}_{50}$ value of $68.83 \mu \mathrm{g} / \mathrm{mL}[16]$.

\section{XOI activity}

The XOI activity is associated with gout incident. XOI inhibits the biosynthesis of uric acid from purine in the body and it has been assumed that either by increasing the excretion of uric acid or reducing the uric acid production helps to reduce the risk of gout [8]. The XOI activity of Yanang leaf extract is shown in Figure 1(c). The XOI activity varied from $72.64 \pm 0.34$ to $79.95 \pm 0.35 \%$ depending on heating temperature and time. The preparation process at $80{ }^{\circ} \mathrm{C}$ for 15 minutes gave the lowest activity at $72.64 \pm 0.34 \%$. During 15 minutes heating at $60{ }^{\circ} \mathrm{C}$, the XOI activity of Yanang leaf extract ranged from $76.65 \pm 0.50$ to $79.95 \pm 0.35 \%$. It ranged from $74.87 \pm 0.27$ to $77.31 \pm 0.37 \%$ and from $72.64 \pm 0.34$ to $76.92 \pm 0.44 \%$ for heating at $70{ }^{\circ} \mathrm{C}$ and $80{ }^{\circ} \mathrm{C}$, respectively. The results showed that an increase in heating temperature and time decreases the XOI activity of Yanang leaf extract. Compared with fresh Yanang leaf extract, a reduction of 1.25-7.90\% in XOI activity was observed in Yanang leaf extract after 15 minutes heating. No research has studied the XOI activity in Yanang leaf extracted with water. However, none XOI activity of methanolic and ethanolic Yanang leaf extracts was reported $[16,17]$. According to the results, heating temperature and time considerably gave huge effect on the chemical properties of Yanang leaf extract. An increase in heating temperature and time decreased total phenolic content, DPPH radical scavenging and XOI activities of Yanang leaf extract.
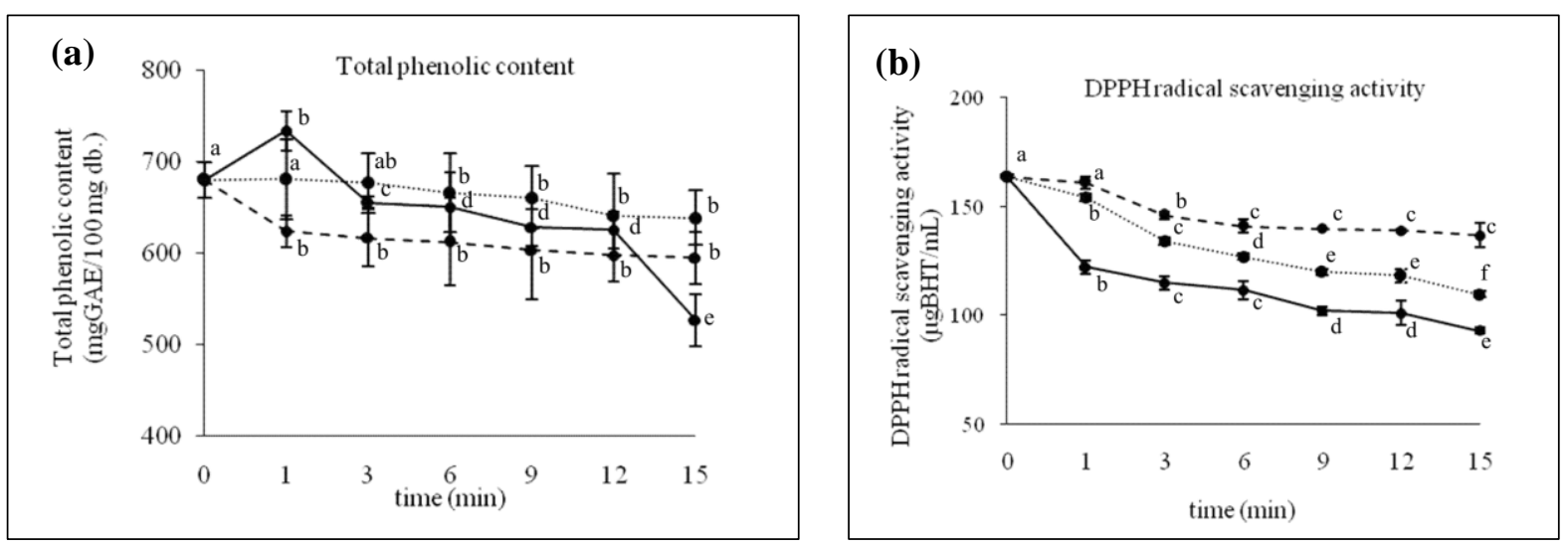
Eadmusik et al: KINETIC DEGRADATION OF TOTAL PHENOLIC CONTENT, DPPH RADICAL SCAVENGING AND XANTHINE OXIDASE INHIBITORY ACTIVITIES IN YANANG (Tiliacora triandra) LEAF EXTRACT DURING PREPARATION PROCESS

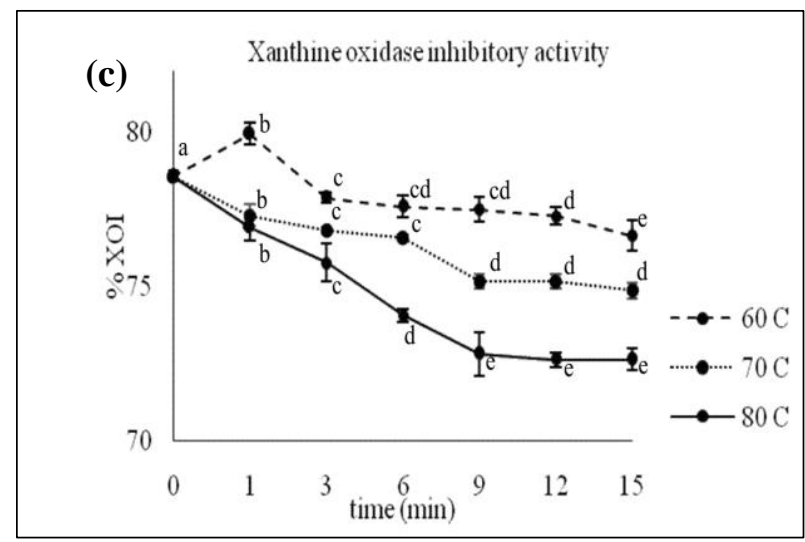

Figure 1. (a) Total phenolic content (b) DPPH radical scavenging activity and (c) XOI activity of Yanang leaf extract during heating at $60{ }^{\circ} \mathrm{C}, 70{ }^{\circ} \mathrm{C}$ and $80{ }^{\circ} \mathrm{C}$ for 15 minutes.

\section{Kinetic degradation of Yanang leaf extract's properties}

Kinetic degradations of total phenolic content, DPPH radical scavenging activity and XOI activity in Yanang leaf extract were determined by performing a regression analysis. The data of degradation were then fitted to three different kinetic models as previous mentioned in equation 2-4. The results revealed that the degradation of total phenolic content at all heating temperatures was described as a zero-order reaction with coefficient of determination between 0.809 and 0.959 (Table 1). The degradations of DPPH radical scavenging and XOI activities were secondorder reactions with coefficient of determination between 0.783 and 0.920 and between 0.864 and 0.922 , respectively.

Table 1. Reaction rate constant $(k)$ and coefficient of determination $\left(\mathrm{R}^{2}\right)$ of total phenolic content, DPPH radical scavenging activity and XOI activity in Yanang leaf extract during preparation process

\begin{tabular}{|c|c|c|c|c|c|c|}
\hline \multirow{3}{*}{ Temperature } & \multirow{2}{*}{\multicolumn{2}{|c|}{$\begin{array}{c}\text { Zero-Order } \\
\text { Total Phenolic Content }\end{array}$}} & \multicolumn{4}{|c|}{ Second-Order } \\
\hline & & & \multicolumn{2}{|c|}{ DPPH Scavenging Activity } & \multicolumn{2}{|c|}{ XOI Activity } \\
\hline & $\begin{array}{c}k \text { (mg GAE } / 100 \\
\text { mg.min) }\end{array}$ & $\mathbf{R}^{2}$ & $k(\mathrm{~mL} / \mu \mathrm{g}$ BHT.min) & $\mathbf{R}^{2}$ & $k(1 / \% . \min )$ & $\mathbf{R}^{2}$ \\
\hline $60{ }^{\circ} \mathrm{C}$ & 2.354 & 0.945 & $8 \times 10^{-5}$ & 0.783 & $2 \times 10^{-5}$ & 0.922 \\
\hline $70{ }^{\circ} \mathrm{C}$ & 3.035 & 0.959 & $2 \times 10^{-4}$ & 0.920 & $4 \times 10^{-5}$ & 0.886 \\
\hline $80{ }^{\circ} \mathrm{C}$ & 12.770 & 0.809 & $2 \times 10^{-4}$ & 0.810 & $7 \times 10^{-5}$ & 0.864 \\
\hline
\end{tabular}

Temperature dependence of the degradations was determined by using Arrhenius equation as described in equation 5. A $\ln k-1 / \mathrm{T}$ graph was plotted in order to express an effect of temperature on reaction rate constant. As shown in Figure 2, the temperature dependence of rate constants followed Arrhenius relationship as indicated by high correlation coefficient which was $0.848,0.764$ and 0.998 for total phenolic content, DPPH radical scavenging activity and XOI activity, respectively. The Arrhenius equations for Yanang leaf extract's properties are shown in Table 2. 

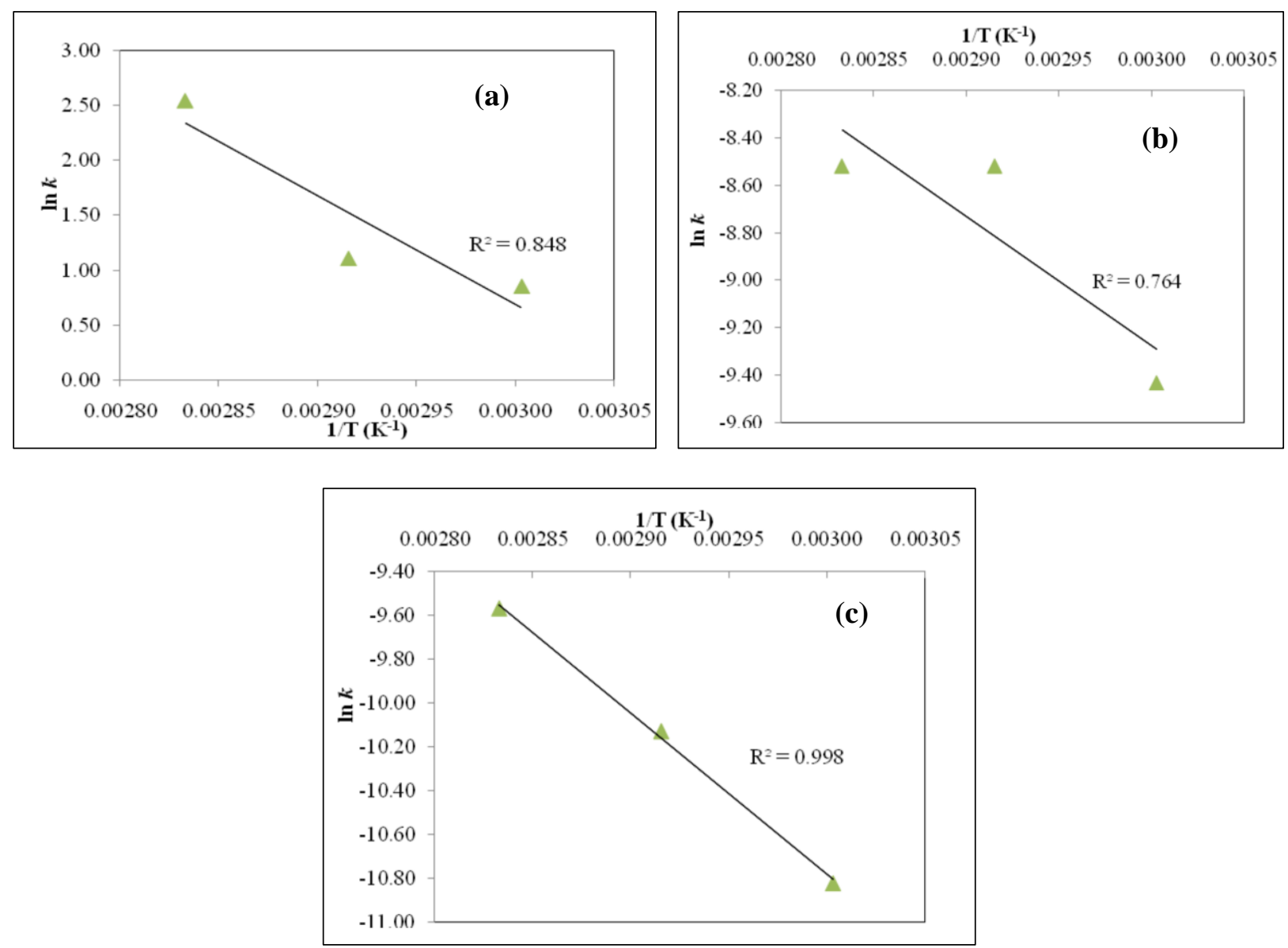

Figure 2. Arrhenius plots of (a) total phenolic content (b) DPPH radical scavenging activity and (c) XOI activity in Yanang leaf extract

Table 2. Arrhenius equation of total phenolic content, DPPH radical scavenging activity and XOI activity degradations in Yanang leaf extract

\begin{tabular}{lcl}
\hline Property & $\mathbf{R}^{\mathbf{2}}$ & Arrhenius Equation \\
\hline Total phenolic content & 0.848 & $k=\exp [(-1186.91 / \mathrm{T})+30.291]$ \\
DPPH scavenging activity & 0.764 & $k=\exp [(-653.86 / \mathrm{T})+7.0355]$ \\
XOI activity & 0.998 & $k=\exp [(-886.29 / \mathrm{T})+11.324]$ \\
\hline
\end{tabular}

\section{Conclusion}

The preparation process of Yanang leaf extract for canned bamboo shoots production degraded its chemical properties. An increase in heating temperature and time decreased the total phenolic content, DPPH radical scavenging activity and XOI activity of the extract. The results showed that Yanang leaf extract contained total phenolic content at 526.33-638.93 mg GAE/100 mg db., DPPH radical scavenging activity at 92.86-136.41 $\mu \mathrm{g}$ $\mathrm{BHT} / \mathrm{mL}$ and XOI activity at $72.64-76.65 \%$. After 15 minutes heating, the total phenolic content, DPPH radical scavenging activity and XOI activity decreased $2.03-22.62 \%, 1.86-43.22 \%$ and $2.80-7.90 \%$, respectively. The degradation of total phenolic content was a zero-order reaction $\left(\mathrm{R}^{2}=0.809-0.959\right)$ while that of DPPH radical scavenging activity $\left(\mathrm{R}^{2}=0.783-0.920\right)$ and XOI activity $\left(\mathrm{R}^{2}=.0864-0.922\right)$ were second-order reactions. Arrhenius 


\section{Eadmusik et al: KINETIC DEGRADATION OF TOTAL PHENOLIC CONTENT, DPPH RADICAL SCAVENGING AND XANTHINE OXIDASE INHIBITORY ACTIVITIES IN YANANG (Tiliacora triandra) LEAF EXTRACT DURING PREPARATION PROCESS}

plots exhibited high coefficient of determination which were $0.848,0.764$ and 0.998 for total phenolic content, DPPH radical scavenging activity and XOI activity, respectively.

\section{Acknowledgement}

This research was funded by King Mongkut's University of Technology North Bangkok (KMUTNB), Thailand. Contract no. KMUTNB-GOV-58-42.1. Authors also would like to thank the Faculty of Agro-industry, KMUTNB Prachinburi campus for the facilities and support.

\section{References}

1. Rattana, S., Cushine, B., Taepongsorat, L. and Phadungkit, M. (2016). Chemical constituents and in vitro anticancer activity of Tiliacora triandra leaves. Pharmacognosy Journal, 8(1): 1-3.

2. Singthong, J., Ningsanond, S. and Cui, S.W. (2009). Extraction and physicochemical characterisation of polysaccharide gum from Yanang (Tiliacora triandra) leaves. Food Chemistry, 114(4): 1301-1307.

3. Rattana, S., Padungkit, M. and Cushnie, B. (2010). Phytochemical screening, flavonoid content, and antioxidant activity of Tiliacora triandra leaf extracts. Proceedings of the $2^{\text {nd }}$ Annual International Conference of Northeast Pharmacy Research: pp. 60-63.

4. Mahidol, C., Sahakitpichan, P. and Ruchirawat, S. (1994). Bioactive natural products from thai plants. Pure and Applied Chemistry, 66(10-11): 2353-2356.

5. Saiin, C. and Markmee, S. (2003). Isolation of anti-malarial active compound from Yanang (Tiliacora triandra Diels). Kasetsart Journal (Natural Science), 37(1): 47-51.

6. Singthong, J., Oonsivilai, R., Oonmetta-aree, J. and Ningsanond, S. (2014). Bioactive compounds and encapsulation of Yanang (Tiliacora triandra) leaves. African Journal of Traditional, Complementary and Alternative Medicine, 11(3): 76-84.

7. Sriket, P. (2014). Chemical components and antioxidant activities of Thai local vegetables. KMITL Science and Technology Journal Part B, 14(1): 18-24.

8. Azmi, S. M. N., Jamal, P. and Amid, A. (2012). Xanthine oxidase inhibitory activity from potential malaysian medicinal plant as remedies for gout. International Food Research Journal, 19(1): 159-165.

9. Saénz, C., Tapia, S., Chávez, J. and Robert, P. (2009). Microencapsulation by spray drying of bioactive compounds from cactus pear (Opuntia ficus-indica). Food Chemistry, 114(2): 616-622.

10. Tian, J., Chen, J., Lv, F., Chen, S., Chen, J., Liu, D. and Ye, X. (2016). Domestic cooking methods affect the phytochemical composition and antioxidant activity of purple-fleshed potatoes. Food Chemistry, 197(Part B): 1264-1270.

11. Turturică, M., Stănciuc, N., Bahrim, G. and Râpeanu, G. (2016). Effect of thermal treatment on phenolic compounds from plum (prunus domestica) extracts - A kinetic study. Journal of Food Engineering, 171: 200207.

12. Méndez-Lagunas, L., Rodríguez-Ramírez, J., Cruz-Gracida, M., Sandoval-Torres, S. and Barriada-Bernal, G. (2017). Convective drying kinetics of strawberry (Fragaria ananassa): Effects on antioxidant activity, anthocyanins and total phenolic content. Food Chemistry, 230: 174-181.

13. De Ancos, B., Sgroppo, S., Plaza, L. and Cano, M.P. (2002). Possible nutritional and health-related value promotion in orange juice preserved by high-pressure treatment. Journal of the Science of Food and Agriculture, 82(8): 790-796.

14. Kalt, W. (2005). Effects of production and processing factors on major fruit and vegetable antioxidants. Journal of Food Sciences, 70(1): R11-R19.

15. Phomkaivon, N. and Areekul, V. (2009). Screening for antioxidant activity in selected thai wild plants. Asian Journal of Food and Agro-Industry, 2(4): 433-440.

16. Taejarernwiriyakul, O., Buasai, M., Rattanatranurak, I., Sriyod, P. and Chanluang, S. (2011). Xanthine oxidase inhibitory activity of medicinal plants. Thai Pharmaceutical and Health Science Journal, 6(1): 1-6.

17. Jiwajinda, S., Santisopasri, V., Murakami, A., Kim, O-K., Kim, H.W. and Ohigashi, H. (2002). Suppressive effects of edible thai plants on superoxide and nitric oxide generation. Asian Pacific Journal of Cancer Prevention, 3(3): 215-223. 